\title{
Cooperation in Hong Kong
}

\section{Hong Kong}

UNLIKE most countries in the West, Hong Kong does not have a history of cooperation between industrial companies and academic institutions, something that has proved to be a drag on the country's competitiveness in high-technology business. But that is now about to change.

Six publicly funded tertiary institutions in the territory have just set up a nonprofit company, Varsity Resources Corporation Ltd, whose aim is to channel academic expertise into the private industrial world. Not only will it allow industrial businesses to improve their research and development skills, but it will provide Hong Kong researchers with a practical outlet for their expertise.

Other countries in the Far East have found various ways to promote such industrial/academic cooperation, but it has usually been done with the services of a political body as a midwife. Taiwan's government, for example, has poured millions of dollars into science parks close to universities and institutes of technology. The government of Singapore has created a 'technology corridor' in which small companies are invited to set up shop close to the national University of Singapore.

Hong Kong is different. Over the years its laissez-faire government has opposed anything that smacks of an industrial policy. According to the Hong Kong government's philosophy, the market is the only effective selector of technological winners and losers. Funding for research and development amounts to no more than 0.04 per cent of Hong Kong's gross domestic product (GDP), a low figure even by Asian standards. By comparison, Western nations such as the United States and Germany spend 2.5-3 per cent of their GDP on research.

Over the past two years, a few Hong Kong companies have become increasingly aware that the colony's industrial sector - which consists predominantly of companies with fewer than 50 employees - lacks some crucial research and development skills. As a result, the territory's technological capacity is falling behind those of Korea, Singapore and Taiwan, the other three 'dragons' that have created strong technology-based economies.

About 18 months ago, Charles Kao, vice-chancellor of Chinese University, who did pioneering research in fibre optics in the $1960 \mathrm{~s}$, decided to do something about the problem. He persuaded six institutions - Chinese University, the University of Hong Kong, the Hong Kong University of Science and Technology, which will open in October, the Hong Kong Baptist College, the Hong Kong NATURE · VOL $352 \cdot 8$ AUGUST 1991
Polytechnic and City Polytechnic of Hong Kong - to work together on a report that would highlight technological opportunities for Hong Kong.

Helped by a grant of HK\$200,000 (US\$25,000) from the Department of Industry, 60-70 professors and lecturers from the six institutions described areas of technology that have particular potential for Hong Kong. The report, entitled Technology Road Maps for Hong Kong: An In-depth Study of Four Technology Areas, was published last month.

The report pinpoints information technology, biotechnology, material technology and environmental technology as four fields that can make the most of Hong Kong's advantages. These include, the report says, excellent telecommunications, a strong entrepreneurial attitude, access to basic research and low-cost labour over the border in China, the availability of technological manpower, access to advanced technology from around the world and a keen perception of worldwide market demands and sentiments.

Projects recommended in the report can be undertaken with relatively small amounts of capital investment.

"Since many such opportunities concern specialized niche products, they may not be readily recognized by businessmen and entrepreneurs," the report says. "The experience of the present study shows that the tertiary education sector is able and ready to deliver technical assistance in identifying and evaluating these potential opportunities."

The scheme offers benefits for academics as well as industrials. At present, explained Robert $\mathrm{Wu}$, director of the Office of Industrial and Business Development at the Chinese University of Hong Kong, the 3,000-4,000 PhDs who live in Hong Kong are largely underused. The six institutions concentrate largely on teaching, and offer few opportunities for research.

The collaborative effort already has one project in the works. It is putting together a team that will bid on a government project in environmental technology one of the four areas spotlighted by the Road Map report. The Hong Kong government wants to identify the effect of its environmental regulations - many of which are not fully enforced - on Hong Kong's manufacturers. Such government contracts, worth many thousands of dollars, normally go to companies based outside Hong Kong.

Further up the road, it is likely that Varsity Resources will help companies to move into fields highlighted by the technology road maps report. Yiu-chung Cheng, director of City Polytechnic, re- ported last week that the group has already received preliminary enquiries from industry.

One academic/industrial partnership in Hong Kong is already flourishing. Last week, computer company Unisys (Hong Kong) Ltd and the City Polytechnic of Hong Kong celebrated the first anniversary of a research and development agreement to develop computing products in various Asian languages by renewing their contract, this time for two years.

The enterprise started with two researchers from City Polytechnic and two from Unisys. Today, the City Polytechnic contingent has risen to ten, while eight Unisys staff members are working on the cooperative project. Later this month, Unisys plans to announce a series of products that the partnership has produced.

So effectively has the project helped the company to develop new products and skills "that I'm surprised that no one in Hong Kong has established similar arrangements," said Roy Clements, general manager of Unisys (Hong Kong). "Our competitors are missing a great opportunity to establish an important market niche." Peter Gwynne

INDIA

\section{Evolution on the air}

New Delhi

ON 2 June, the state owned All-India Radio (AIR) embarked on a massive science popularization programme - a 130-part serial on human evolution. Aired every Sunday in 17 languages from 51 radio stations, the serial will run for two-and-half years.

In all, 10,000 schools and 100,000 children from 10 to 14 years old are 'registered' listeners. They were signed up before the programme was launched and given a set of supplementary printed material and 'activity kits' - one set for each child and five sets for each school designed to supplement the knowledge gained from the broadcasts.

Listeners can mail their queries to the nearest radio station and have them answered on later shows. One transmission after every three broadcasts is devoted to answering questions and after every 20 episodes listeners will participate in a quiz competition, with winners visiting Delhi to receive their prizes.

The Madras station alone has received 2,500 queries, mostly from children in rural areas without television.

The first prime minister of India, Jawaharlal Nehru, blamed India's backwardness on lack of scientific knowledge among the masses and urged scientists to teach them the scientific method. The radio serial, which will end in December of 1993, is a step in that direction.

K. S. Jayaraman 